\title{
Selective ligands of estrogen receptor $\beta$ discovered using pharmacophore mapping and structure-based virtual screening
}

\author{
Lei CHEN ${ }^{1, \#}$, Dang WU ${ }^{1, \#}$, Han-ping BIAN ${ }^{1}$, Guang-lin KUANG ${ }^{1}$, Jing JIANG ${ }^{1}$, Wei-hua LI $^{1}$, Gui-xia LIU ${ }^{1}$, Shi-en ZOU ${ }^{2, *}$, Jin \\ HUANG $^{1}$, Yun TANG ${ }^{1, *}$ \\ ${ }^{1}$ Shanghai Key Laboratory of New Drug Design, School of Pharmacy, East China University of Science and Technology, Shanghai \\ 200237, China; ${ }^{2}$ Department of Gynecology, Obstetrics and Gynecology Hospital, Fudan University, Shanghai 200011, China
}

\begin{abstract}
Aim: To discover novel ligands of estrogen receptor (ER) $\beta$ using pharmacophore mapping and structure-based screening. Methods: A computer-aided strategy combining pharmacophore mapping and structure-based screening was used to screen the Maybridge and Enamine databases. Yeast two-hybrid $(\mathrm{Y} 2 \mathrm{H})$ assay was used to detect the activity and selectivity of the chosen compounds. The transcriptional activities of the chosen compounds were demonstrated with luciferase reporter assays. The antiproliferative effects of ER antagonists against MCF-7 and MDA-MB-231 breast cancer cells were examined using MTT assay, and the mechanisms of action were analyzed with flow cytometry analysis and Western blotting.

Results: Through in silico screen, 95 compounds were chosen for testing in $\mathrm{Y} 2 \mathrm{H}$ assay, which led to 20 potent ligands, including 10 agonists, 8 antagonists and 2 partial agonists with $\mathrm{EC}_{50}$ or $\mathrm{IC}_{50}$ values at $\mu \mathrm{mol} / \mathrm{L}$. Furthermore, 6 agonists exhibited absolute selectivity for ERß, and 3 agonists showed higher selectivity for ERß. The agonists $1 \mathrm{~g}$ and $\mathbf{1 h}$ (10, 25, and $50 \mu \mathrm{mol} / \mathrm{L})$ dose-dependently increased ER transcriptional activities, whereas the antagonists $2 a$ and $\mathbf{2 d}(10,25$, and $50 \mu \mathrm{mol} / \mathrm{L})$ caused dose-dependent inhibition on the activities. The antagonists and partial agonists at $100 \mu \mathrm{mol} / \mathrm{L}$ suppressed the proliferation of ER $\alpha$ positive MCF-7 cells and ERß positive MDA-MB-231 cells, but were more effective against MDA-MB-231 cells. Treatment of MDA-MB-231 cells with antagonists $\mathbf{2 a}$ and $\mathbf{2 d}(25$ and $50 \mathrm{\mu mol} / \mathrm{L})$ dose-dependently increased the population of cells in the S phase. Both $\mathbf{2 a}$ and $\mathbf{2} \mathbf{d}$ treatment dosedependently decreased the expression levels of cyclin A and CDK2. Meanwhile, the downregulation of cyclin E was only caused by $2 \mathrm{~d}$, while 2a treatment did not cause significant changes in the protein levels of cyclin $\mathrm{E}$.

Conclusion: The selective ligands discovered in this study are promising drug candidates to be used as molecular probes to explore the differences between $E R \alpha$ and $E R \beta$.
\end{abstract}

Keywords: estrogen receptor; subtype-selective ligand; estradiol; tamoxifen; pharmacophore mapping; structure-based virtual screening; breast cancer; anti-proliferation; cell cycle arrest

Acta Pharmacologica Sinica (2014) 35: 1333-1341; doi: 10.1038/aps.2014.69; published online 1 Sep 2014

\section{Introduction}

Breast cancer is one of the most common epithelial tumors and has been a major source of mortality among women. Many studies have shown that exposure to estrogen is an important induction factor for breast cancer. Blocking estrogen action represents an effective approach for breast cancer treatment. However, estrogen plays key roles in maintaining normal functions of the human body, such as reproductive, skeletal,

\footnotetext{
\# These authors contributed equally to this work.

* To whom correspondence should be addressed.

E-mail ytang234@ecust.edu.cn (Yun TANG); zoushien@fudan.edu.cn (Shi-en ZOU)

Received 2014-02-21 Accepted 2014-06-03
}

cardiovascular and nervous system functions, by binding with estrogen receptors. Therefore, simply blocking estrogen action could adversely affect the body; therefore, selective estrogen receptor modulators are required.

Estrogen receptors belong to the nuclear receptor superfamily. They can be activated by estrogen, and in response, estrogen receptors bind to DNA and regulate the expression of target genes. To date, two forms of estrogen receptors, ERa and ER $\beta$, have been identified. In spite of their significant sequence homology, there are notable differences in distribution and function of these receptors: ERa is predominantly expressed in bone, breast, prostate (stroma), uterus, ovary (thecal cells) and brain, whereas ER $\beta$ is usually present in 
ovary (granulose cells), bladder, colon, immune, cardiovascular and nervous systems $\mathrm{s}^{[1-4]}$.

ERa is responsible for the classic function of estrogen, and its antagonists could have anti-proliferative effects through the inhibition of estrogen binding. Meanwhile, activating ER $\beta$ may have anti-proliferative effects and therefore oppose the actions of ERa in reproductive tissue ${ }^{[5]}$. Thus, ER $\beta$ is a potent tumor suppressor and plays a crucial role in many cancer types ${ }^{[6]}$. Selective ER $\beta$ ligands are able to suppress breast cancer cell proliferation without stimulating the uterus. In addition, it has been reported that ER $\beta$ might be related to diabetes and inflammation ${ }^{[7-9]}$. Existing data also suggest that selective activation of ER $\beta$ may treat Alzheimer's disease ${ }^{[10]}$. However, these two subtypes of estrogen receptors are almost identical, and only two residues differ in the ligand binding pockets (LBP). Therefore, we are faced with a certain challenge in obtaining subtype-selective ligands. To date, some $E R \beta$-selective scaffolds, such as geinstein and DPN, have been discovered ${ }^{[1,11]}$. These nonsteroidal ligands are not only important probes to explore the biological effects of $E R \beta$, but some of them also show potential for therapy ${ }^{[12,13]}$.

Structure-based virtual screening is an effective method for finding bioactive ligands with a novel scaffold. In fact, virtual screening was applied in the search of ER ligands in our previous work ${ }^{[14]}$. However, this method is time-consuming and focuses on the fitness between ligands and the protein. Considering those known selective ER $\beta$ ligands, ligand-based method such as pharmacophore modeling might provide additional information for subtype selectivity. A pharmaco- phore model is a hypothesis of molecular features necessary for the bioactivity of a ligand. Typical pharmacophore features usually include hydrophobes, hydrogen bond acceptors or donors, aromatic rings, cations or anions. Based on these chemical features, some hit compounds retrieved by pharmacophore screening are similar to known active ligands, while some others are novel scaffolds. Therefore, pharmacophore screening is not only a valuable tool for scaffold hopping, but is also time-saving. In our previous work, subtype-specific pharmacophore models were developed for both ERa and $E R \beta$, which were capable of capturing selective ligands ${ }^{[15]}$.

In this study, a strategy combining pharmacophore and structure-based virtual screening was performed to discover novel ER $\beta$ selective ligands from two commercial databases (Figure 1). Maybridge and Enamine databases were first screened by our pharmacophore model of ER $\beta$ selectivity, and then molecular docking was conducted in the second filtering. Finally, 95 selected compounds were purchased and tested using a yeast two-hybrid ( $\mathrm{Y} 2 \mathrm{H})$ assay. Among the tested hits, 20 compounds were active and an MTT assay was performed on MCF-7 and MDA-MB-231 cells. The mechanism underlying the cell growth suppression of compounds $\mathbf{2 a}$ and $\mathbf{2} \mathbf{d}$ was studied further.

\section{Materials and methods}

Virtual screening

ER $\beta$ pharmacophore was used to screen Maybridge and Enamine databases using Discovery Studio 2.1 in the first round ${ }^{[16]}$. The top 5000 ranked compounds were subjected to
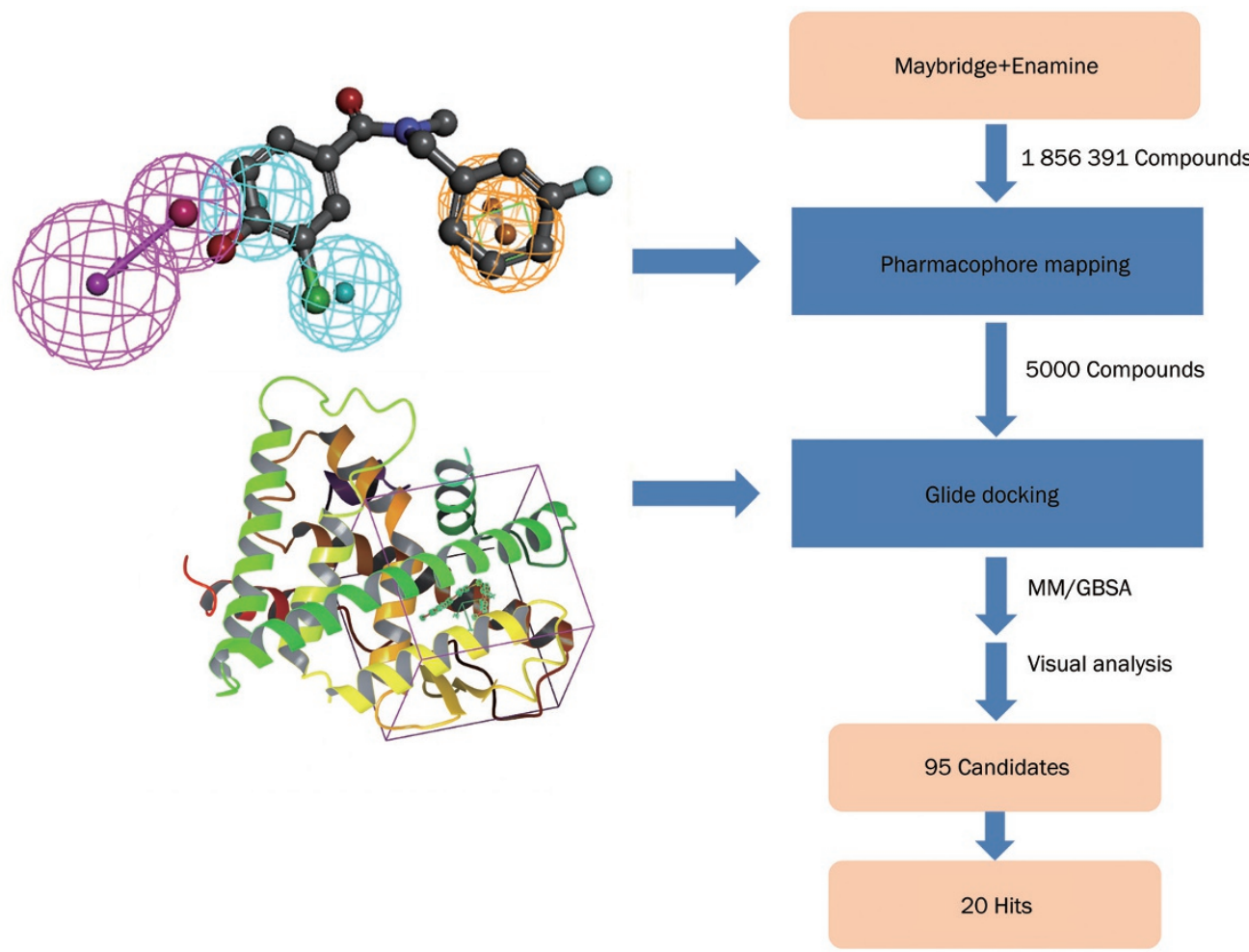

Figure 1. Scheme of the strategy combining pharmacophore and struture-based virtual screening in this study. 
the following structure-based screening. The crystal structure (PDB 1X78) was prepared using the Protein Preparation Wizard in the Schrödinger software package and was then used to filter compounds with standard precision in the second round. Next, MM-GBSA was adopted to estimate binding affinity ${ }^{[17]}$. Through visual analysis, 95 compounds were finally selected for purchase from vendors for use in bioassays.

\section{Yeast two-hybrid assay}

Yeast transformation and the a-galactosidase activity assay were carried out as previously described to evaluate the activity and selectivity of the compounds. Briefly, the yeast strain AH109 was co-transformed with pGADT7-SRC1 (aa 613-773) and pGBKT7-ER LBD (aa 301-553 of ERa and 248-510 of ER $\beta$ ). In agonist assays, the yeast transformants were incubated with the tested compounds for $24 \mathrm{~h}$, and in antagonist assays, 1 nmol/L E2 should be added. The a-galactosidase activity was determined by the method of the Clontech manual.

\section{Cell transfection and luciferase reporter assay}

CHO-K1 cells were cultured in phenol red-free DMEM/F12 supplemented with $10 \%$ charcoal-stripped FBS at $37^{\circ} \mathrm{C}$ in an atmosphere of $5 \% \mathrm{CO}_{2}$. Then, cells were plated in 24-well plates at $1 \mathrm{~d}$ before transfection. Subsequently, cells were cotransfected with the reporter construct pGL2-ERE3-luc and ER expression plasmids pRST7-ERa or pCMV5-ER $\beta$ using lipofectamine 2000 (Invitrogen) according to the manufacturer's recommendations. The pRL-SV40 renilla luciferase plasmid was also transfected into cells, which served as an internal control for normalizing the results. After $5 \mathrm{~h}$, the transfection medium was replaced with fresh medium containing different concentrations of compounds and the cells were incubated for an additional $24 \mathrm{~h}$. Dual-luciferase assays were performed using the Dual-Luciferase Reporter Assay System (Promega) to measure the luciferase activity according to the manufacturer's instructions. All transfections were performed in triplicate.

\section{MTT assay}

The MTT assay was performed to measure cell viability and proliferation. Briefly, the MCF-7 and MDA-MB-231 cells were seeded in 96-well plates with phenol red-free DMEM/F12 supplemented with $10 \%$ charcoal-stripped FBS at the density of $10^{5}$ cells $/ \mathrm{mL}$. The cells were incubated with the tested compounds with a series of concentrations $(0.01,0.1,1.0,10,25,50$, and $100 \mu \mathrm{mol} / \mathrm{L})$ at $37^{\circ} \mathrm{C}$ in a humidified atmosphere with $5 \%$ $\mathrm{CO}_{2}$ for $48 \mathrm{~h}$. Then, the cells in each well were treated with 20 $\mu \mathrm{L}$ of $5 \mathrm{mg} / \mathrm{mL}$ MTT and maintained for another $4 \mathrm{~h}$. Absorbance at $570 \mathrm{~nm}$ was determined with a Synergy 2 multimode microplate reader (BioTek) after the formazan crystals were dissolved with $150 \mu \mathrm{L}$ of DMSO.

\section{Cell cycle analysis}

MDA-MB-231 cells were seeded into 6-well plates at a density of $2 \times 10^{5}$ per well and treated with various concentrations of 2a or $\mathbf{2 d}$ for 48 h. Cells were harvested, washed twice with cold PBS, and fixed in $70 \%$ ethanol at $4{ }^{\circ} \mathrm{C}$ overnight. Then, the pellets were rinsed in PBS and resuspended in $1 \mathrm{~mL}$ PBS containing $50 \mu \mathrm{g}$ RNase for $30 \mathrm{~min}$ at $37^{\circ} \mathrm{C}$ before addition of propidium iodide $(50 \mu \mathrm{g} / \mathrm{mL})$ for DNA staining in the dark at $4^{\circ} \mathrm{C}$ for $30 \mathrm{~min}$. Cell cycle distribution in $\mathrm{G}_{0} / \mathrm{G}_{1}, \mathrm{~S}$, and $\mathrm{G}_{2} / \mathrm{M}$ phase was analyzed using the BD FACSCalibur flow cytometer and ModFit software (Verity Software House Inc, Topsham, ME, USA).

\section{Western blot}

MDA-MB-231 cells were cultured with DMEM/F12 supplemented with $10 \%$ charcoal-stripped FBS and seeded into 6 -well plates at a density of $2 \times 10^{5}$ cells/well. Then, cells were treated with $1 \mathrm{nmol} / \mathrm{L}$ E2 and different concentrations of $\mathbf{2 a}$ or $2 \mathrm{~d}$ for $48 \mathrm{~h}$. After that, the cells were washed twice with icecold PBS and lysed in lysis buffer $(20 \mathrm{mmol} / \mathrm{L}$ Tris, $\mathrm{pH} 7.5$, $150 \mathrm{mmol} / \mathrm{L} \mathrm{NaCl}, 1 \%$ Triton $\mathrm{X}-100$ ) containing protease and phosphatase inhibitors for $30 \mathrm{~min}$ on ice. After centrifugation at $10000 \times \mathrm{g}$ at $4^{\circ} \mathrm{C}$ for $10 \mathrm{~min}$, equal amounts $(60 \mu \mathrm{g})$ of cell lysates (supernatant) were separated by 12\% SDS-PAGE and transferred to PVDF membrane (Millipore). Then, the membrane was blocked in 5\% non-fat milk in TBST buffer for $1 \mathrm{~h}$, and incubated with anti-cyclin A, anti-cyclin E and anti-cdk2 antibodies (Bioworld) at $4{ }^{\circ} \mathrm{C}$ overnight, followed by horseradish peroxidase-conjugated secondary antibodies. Bound antibodies were measured and quantified using an enhanced chemiluminescence (ECL) system (Amersham Pharmacia Biotech, Piscataway, NJ, USA).

\section{Results}

\section{Virtual screening}

1856391 compounds from the Maybridge and Enamine databases were filtered by ER $\beta$ pharmacophore, which contained four features: one aromatic ring, one hydrogen bond donor and two hydrophobes. According to the fitness, the top 5000 ranked compounds were stored for the next docking-based screening with ER $\beta$ crystal structure (PDB 1X78). Docking score and Molecular Mechanics-Generalized Born Surface Area (MM-GBSA) were adopted in this process. Additionally, we visually analyzed the compound binding poses by forming one or more H-bonds with Glu305 or Arg346 plus an edge-toface $\Pi-\Pi$ interaction with Phe356. Finally 95 compounds were selected and purchased for bioassay.

\section{In vitro agonistic and antagonistic activity}

It has been previously demonstrated that a yeast two-hybrid $(\mathrm{Y} 2 \mathrm{H})$ system, through the combination of the human ERa or ER $\beta$ and co-activator SRC1 in the AH109 yeast strain, could be used as a rapid, sensitive and reproducible method to detect novel ER ligands. Among the 95 compounds, 20 (Figure 2) were confirmed to be active to ERa or ER $\beta$ in the $\mathrm{Y} 2 \mathrm{H}$ system. Table 1 shows the activities of these bioactive compounds and their effects on the biological behaviors of breast cancer cells. In these ligands, 10 compounds showed agonistic activity, and 8 had antagonistic activity. Compounds $\mathbf{3 a}$ and $\mathbf{3 b}$ were indicated as partial agonists of ERa. The majority of the com- 
<smiles>[R]c1cc(C(=O)N(C)Cc2ccccc2[R])ccc1O</smiles>

1a, $1 d$

$\begin{array}{ccc}\text { Compound } & \mathrm{R}_{1} & \mathrm{R}_{2} \\ \text { 1a } & \mathrm{Cl} & m-\mathrm{F} \\ \text { 1d } & \mathrm{H} & \mathrm{o}-\mathrm{F}\end{array}$<smiles>[R]C([R])=C(C)c1ccc([R])c([R])c1[R3]</smiles>

$1 \mathrm{~g}, 1 \mathrm{i}, 2 \mathrm{c}-\mathrm{d}$

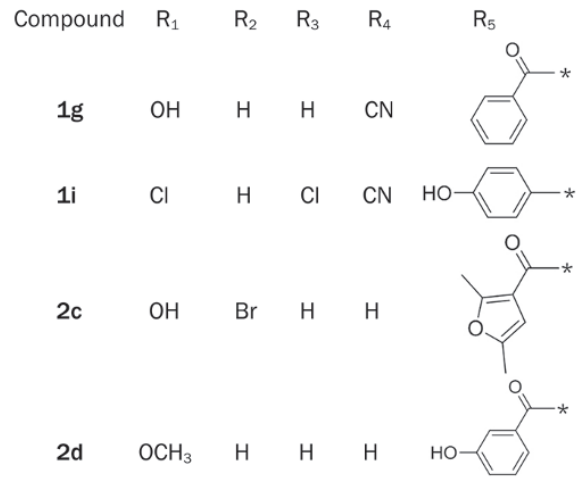<smiles></smiles>

$1 \mathrm{c}, 1 \mathrm{e}$

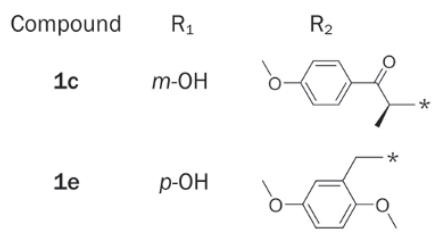

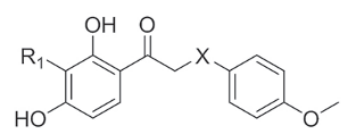

$2 b, 3 a$

$$
\begin{array}{ccc}
\text { Compound } & \mathrm{R}_{1} & \mathrm{X} \\
\text { 2b } & \mathrm{CH}_{3} & \mathrm{O} \\
\text { 3a } & \mathrm{H} & \mathrm{S}
\end{array}
$$

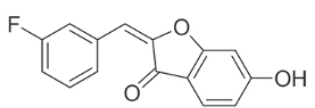

1h
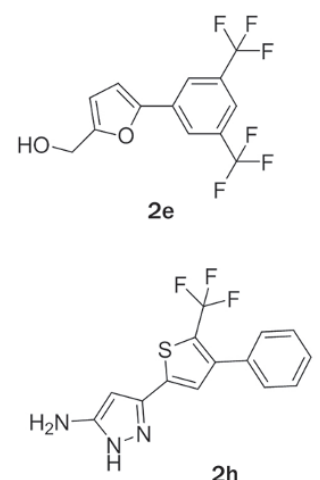

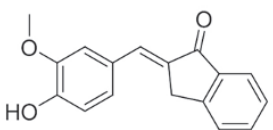

1j

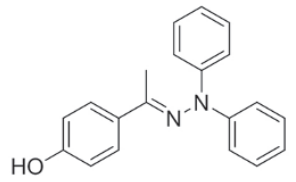

$2 a$<smiles>N#CC(=C1C=CC(=NO)C(Br)=C1)c1ccc(Cl)cc1</smiles>

$2 f$<smiles>CCN1C(=O)/C(=C\c2ccc(O)cc2)SC1=S</smiles>

3b

Figure 2. Structures of ER ligands discovered in this study.

pounds had potent activities for both subtypes, with $\mathrm{EC}_{50}$ or $\mathrm{IC}_{50}$ values below $10 \mu \mathrm{mol} / \mathrm{L}$. Of the agonists, 9 compounds $(\mathbf{1 a}-\mathbf{1 h}, \mathbf{1 j})$ had selective activity for ER $\beta$, and 6 compounds (1a-1f) showed absolute ER $\beta$ selectivity. $\mathrm{EC}_{50}$ values of the most potent agonist (1i) were 0.130 and $0.0647 \mu \mathrm{mol} / \mathrm{L}$ for ER $\beta$ and ERa, respectively. To determine the agonistic effectiveness of these compounds, we also evaluated the $10 \%$ relative effective concentration $\left(\mathrm{REC}_{10}\right)$, which is the concentration of the tested compound that shows $10 \%$ agonistic activity of $17 \beta$-estrodial (E2). The $\mathrm{REC}_{10}$ values were interrelated with $\mathrm{EC}_{50}$ for most compounds. As for antagonists, although they mostly had equal activity to both subtypes in $\mathrm{Y} 2 \mathrm{H}$ assay, some of them exhibited selective anti-proliferative against ER $\beta$ positive MDA-MB-231 such as $\mathbf{2} \mathbf{b}$ and $\mathbf{2 e}$ (Table 1 ).

\section{Transcriptional activity}

To estimate the impacts of some agonists and antagonists which had better activities in the $\mathrm{Y} 2 \mathrm{H}$ assay on biological systems, we investigated the transcriptional activity of $\mathbf{1 g}$, 1h (agonists) and 2a, 2d (antagonists) using a transactivation assay. Due to a high degree of transfectability, CHO-K1 cells were used for the luciferase reporter assay experiment as described in the Methods. CHO-K1 cells were cotransfected with expression plasmids encoding either ERa or ER $\beta$, where the luciferase reporter plasmid is driven by ERE, together with a renilla luciferase control plasmid pRL-SV40. Then, cells were treated with different concentrations of compounds. The results of transcriptional activation or repression are shown in Figure 3. As expected, $\mathbf{1 g}$ and $\mathbf{1 h}$ exhibited a dose-responsive increase in ER transcriptional activity. These agonists had agonistic activity on both ERa and ER $\beta$, and resulted in higher ERE reporter activity at high concentration in comparison to E2 (Figure 3A and 3B). For antagonists, $2 \mathrm{a}$ and $\mathbf{2 d}$ could inhibit the reporter gene transcription in a dose-dependent manner and block the luciferase induction back to control levels at maximum concentration (Figure 3C and 3D).

\section{Anti-proliferative activity and the mechanism of action}

Previous studies indicated that the inhibition of the ER may have anti-tumoral potential against different cancers. Based on the results of the $\mathrm{Y} 2 \mathrm{H}$ and luciferase assays, it was predicted that ER antagonists would inhibit proliferation of breast cancer cells. The effects of the compounds on cell proliferation and viability were evaluated using the MTT assays against two breast cancer cell lines, MCF-7 and MDA-MB-231. Cells were treated for $48 \mathrm{~h}$ with increasing doses of compounds and 
Table 1. Agonistic or antagonistic activities of the tested compounds and standard compounds on both ER subtypes ${ }^{a}$.

\begin{tabular}{|c|c|c|c|c|c|c|c|c|}
\hline & & $E R \beta$ & & & $E R \alpha$ & & Selectivity & MCF-7 MDA-MB-231 \\
\hline Compd & $\mathrm{IC}_{50}(\mu \mathrm{mol} / \mathrm{L})$ & $\mathrm{EC}_{50}(\mu \mathrm{mol} / \mathrm{L})$ & $\mathrm{REC}_{10}{ }^{\mathrm{b}}$ & $\mathrm{IC}_{50}(\mu \mathrm{mol} / \mathrm{L})$ & $\mathrm{EC}_{50}(\mu \mathrm{mol} / \mathrm{L})$ & $\mathrm{REC}_{10}{ }^{\mathrm{b}}$ & $\alpha / \beta^{c}$ & $\begin{array}{cc}\text { inhibition } & \text { inhibition } \\
(\%)^{d} & (\%)\end{array}$ \\
\hline
\end{tabular}

\begin{tabular}{lcl}
\hline Agonists & & \\
1a & $1.41 \pm 0.20$ & 0.620 \\
1b & $1.56 \pm 0.48$ & 0.0298 \\
1c & $3.49 \pm 0.21$ & 0.320 \\
1d & $19.3 \pm 0.85$ & 12.4 \\
1e & $1.13 \pm 0.61$ & 1.20 \\
1f & $25.5 \pm 0.27$ & 0.600 \\
1g & $2.97 \pm 0.28$ & 0.470 \\
1h & $0.910 \pm 0.20$ & 0.200 \\
1i & $0.130 \pm 0.19$ & 0.146 \\
1j & $0.630 \pm 0.21$ & ND \\
Estradiol & $0.00108 \pm 0.00007$ & 0.000183
\end{tabular}

$\begin{array}{cll}6.74 \pm 0.19 & 8.17 & 2.27 \\ 1.85 \pm 0.17 & 1.30 & 2.03 \\ 0.0647 \pm 0.00033 & 0.0450 & 0.50 \\ 2.36 \pm 0.18 & 1.12 & 3.75 \\ 0.00105 \pm 0.00006 & 0.0001 & 0.97\end{array}$

Antagonists

$\begin{array}{ll}2 \mathrm{a} & 3.52 \pm 0.95 \\ 2 \mathrm{~b} & 7.29 \pm 1.0 \\ \mathrm{2c} & 7.81 \pm 0.28 \\ \mathrm{2d} & 0.62 \pm 0.27 \\ \mathrm{2e} & 21.7 \pm 0.57 \\ \mathrm{2f} & \\ \mathbf{2 g} & 0.810 \pm 0.33 \\ \mathrm{2h} & 9.02 \pm 0.12\end{array}$

Tamoxifen $\quad 1.66 \pm 0.010$

Partial agonists

\begin{tabular}{llllllllll} 
3a & $5.48 \pm 0.75$ & $3.74 \pm 0.33$ & 0.064 & $1.96 \pm 0.28$ & $1.31 \pm 0.13$ & 2.03 & 0.35 & 5.48 & 97.98 \\
3b & & & $1.19 \pm 0.95$ & $0.33 \pm 0.21$ & 0.39 & & 25.31 & ND \\
\hline
\end{tabular}

${ }^{a}$ Data shown are the mean \pm SD for at least triplicate measurements determined by $\mathrm{Y} 2 \mathrm{H}$ assays. This system employs the interaction between human ER LBD and the coactivator SRC 1 (see Experimental section).

${ }^{\mathrm{b}} 10 \%$ relatively effective concentration, which is the concentration of the tested chemical showing $10 \%$ of agonistic activity of the maximum activity of E2. $R C_{10}$ provides the estrogenic activity relative to that of $E 2$.

${ }^{c}$ Determined by $\mathrm{EC}_{50}$ on $\mathrm{ER} \alpha$ and $\mathrm{ER} \beta$ for agonists and by $\mathrm{IC}_{50}$ of $\mathrm{ER} \alpha$ and $\mathrm{ER} \beta$ for antagonists.

${ }^{d}$ Relative inhibition rate of anti-proliferative potency determined by MTT assays. The final concentration of the compounds is $100 \mu$ mol/L, and cells treated with DMSO as control were set to $100 \%$ viability. ND: not determined.

then cell proliferation was measured by the MTT method. As expected, ERa-positive MCF-7 cells showed inhibited growth by three compounds, and $70 \%-90 \%$ inhibitory ratios were detected (Table 1). Meanwhile, exposure to these antagonists except $3 \mathbf{b}$, which only had antagonism to ERa, also limited proliferation of the MDA-MB-231 cell line. A stronger antiestrogen response occurred in this cell line, where robust growth inhibition was greater than $98 \%$. Only in MDAMB-231 cells, but not in MCF-7 cells, did treatment with compounds $\mathbf{2} \mathbf{b}, \mathbf{2} \mathbf{e}$, and $\mathbf{3} \mathbf{a}$ significantly reduce the cell viability. These data suggested that these antagonists showed higher antagonistic activity for ER $\beta$ by contrast with ERa. Thus, MDA-MB-231 cells were chosen for the following studies.

To further investigate the mechanism underlying the cell growth suppression caused by compounds $\mathbf{2 a}$ and $\mathbf{2 d}$, which showed relatively higher antiproliferative potencies on breast cancer cells, flow cytometry was carried out to analyze the cell cycle distribution after treatment of MDA-MB-231 cells with 50 $\mu \mathrm{mol} / \mathrm{L} \mathbf{2} \mathbf{a}$ or $\mathbf{2} \mathbf{d}$ for $48 \mathrm{~h}$. The cells treated with compounds were collected and fixed in $70 \%$ ethanol in $4^{\circ} \mathrm{C}$ overnight followed by staining with propidium iodide. Then, the DNA content was determined through FACS analysis. As shown in Figure 4, compared to the control cells, treatment of MDAMB-231 cells with $50 \mu \mathrm{mol} / \mathrm{L} \mathbf{2 a}$ and $\mathbf{2 d}$ resulted in an increase in the population of cells in the S phase $(25.83 \%$ vs $14.21 \%$ and $30.52 \%$ vs $14.21 \%$ ), which indicated that $2 \mathrm{a}$ and $2 \mathrm{~d}$ caused a $S$ phase blockade in MDA-MB-231 cell, and then reduced the cell proliferation.

The cell cycle is regulated by a series of checkpoints involving cyclins and cyclin-dependent kinases (CDKs). It has been reported that $\mathrm{S}$ phase progression is directed by the cyclin $\mathrm{A} / \mathrm{CDK} 2$ complex, and another complex, cyclin E/CDK2 is 
A
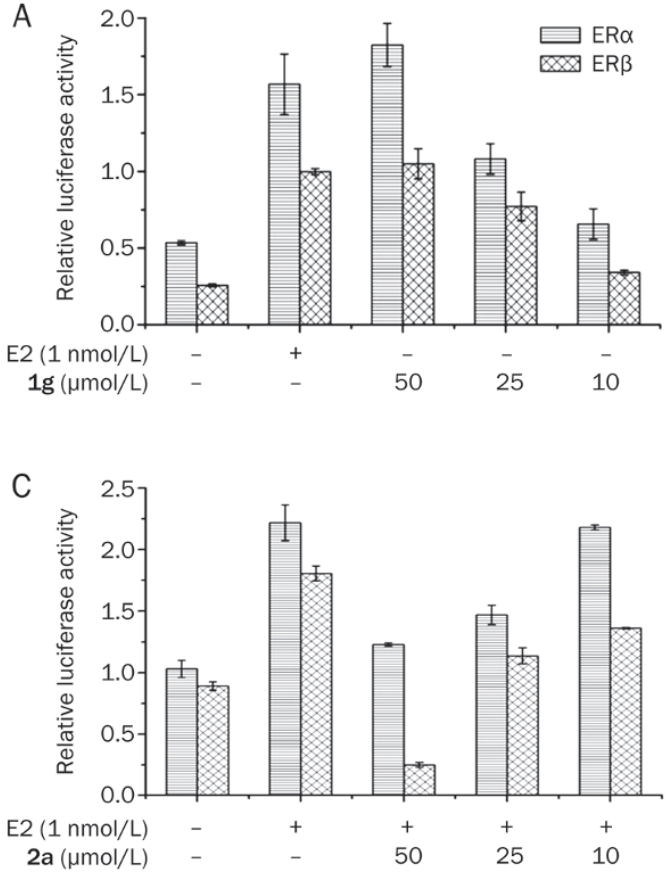
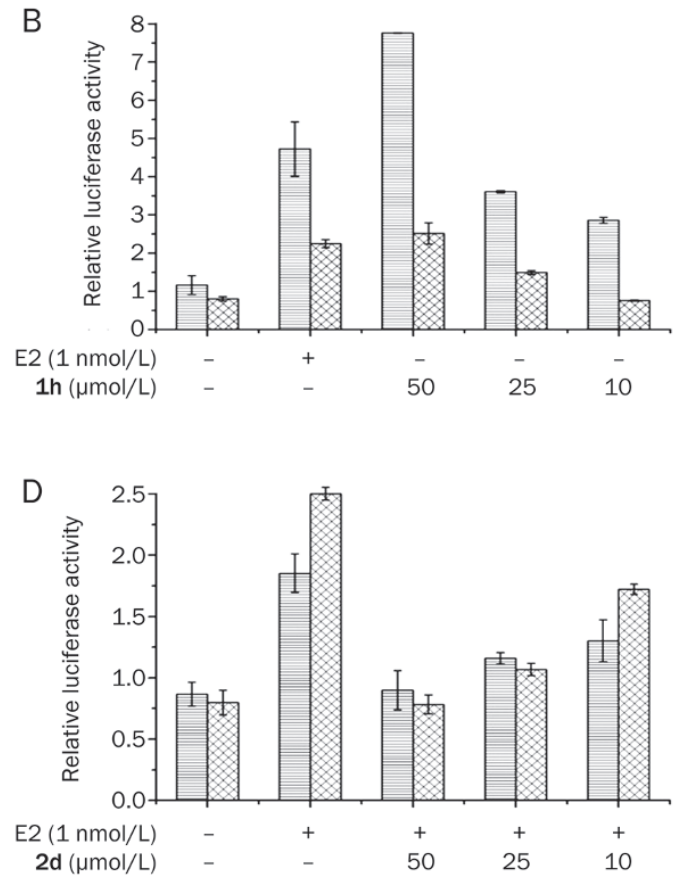

Figure 3. Effects of ER ligands on ERE-luciferase activity in CHO-K1 cells. Two agonists $\mathbf{1 g}(\mathrm{A})$ and $\mathbf{1 h}$ (B) and two antagonist $\mathbf{2 a}(\mathrm{C})$ and $\mathbf{2 d}$ (D) were selected to evaluate the ERE-luciferase activity in CHO-K1 cells The transcriptional activation or repression of compounds was assessed using DualLuciferase assays. CHO-K1 cells were transfected with expression vectors for ER $\alpha$ or ER $\beta$ and an ERE-driven reporter plasmid, and a Renilla luciferase expression plasmid (as transfection control). Cells were treated with compounds at the concentrations indicated. The results were expressed as the ratio of the firefly luciferase activity to the Renilla luciferase activity, and the luciferase activity was relative to that of the control cells treated with DMSO which was set as 1.0. Results were expressed as the mean \pm SD of three independent experiments.

necessary in the transition from $G_{1}$ to $S$ phase. To further identify whether the ER antagonists $\mathbf{2 a}$ and $\mathbf{2 d}$, cause $S$ phase arrest, which could alter the expression of $S$ phase-specific cell cycle regulatory proteins, a protein extract was prepared from compound-treated cells for $48 \mathrm{~h}$, and the expression levels of cyclin A, CDK2, and cyclin E were detected by immunoblotting. We observed that $\mathrm{E} 2$ increased the expression of these regulators, whereas both $\mathbf{2 a}$ and $\mathbf{2 d}$ treatment dose-dependently decreased the expression levels of cyclin A and CDK2 (Figure 5). Meanwhile, the downregulation of cyclin E was only caused by $\mathbf{2} \mathbf{d}$, while $\mathbf{2 a}$ treatment did not cause significant changes in the protein levels of cyclin E. Taken together, these results suggest that the two tested ER antagonists could attenuate E2 induction, and subsequently induce $S$ phase cell cycle arrest through the down-regulation of cyclin A, CDK2, and cyclin E in MDA-MB-231 cells.

\section{Discussion}

Currently, virtual screening is no longer confined to individual application of structure- or ligand-based methods. A combined strategy is proposed to take full advantage of available chemical and biological information, which can reduce the weakness and enhance the strengths of the individual method ${ }^{[18]}$. We designed a good virtual screening protocol that saved computational resources as well as time (Figure 1). In this protocol, ligand-based pharmacophore filtering that considered the features essential for selective ER $\beta$ ligands bind- ing, and structure-based molecular docking that focused the shape and interaction fitness between compounds and ER $\beta$, complemented each other. As we expected, the results of the bioassays indicated that these compounds were mostly ER $\beta$ selective, which demonstrated our protocol to be effective.

Similar to known ER ligands, most of the active compounds discovered in our work contained a hydroxyl group. As shown in Figure 6E, the hydroxyl group of compound 1a was fitted onto the hydrogen bond donor feature (HD feature) of the ER $\beta$ pharmacophore, which was essential for ER $\beta$ activity. The other three features, including two hydrophobes and one aromatic ring, were also well matched by a phenolic ring, chlorine atom and fluorobenzene, respectively. The docking pose of 1a demonstrated that the phenolic part occupied the hydrophobic pocket (S1 subset) of ER $\beta$. The S1 subset was composed of residues Leu301, Ala302, Glu305, Met336, Leu339, Met340, Leu343, Arg346, Phe356, and Leu380 (Figure $6 \mathrm{E}$ ). The hydroxyl group of $1 \mathrm{a}$ formed hydrogen bonds with Arg346 and Glu305. This hydrogen bond network was a classical interaction between estrogen receptor and ligands. Meanwhile an "edge to face" $\Pi-\Pi$ interaction was observed between Phe356 and the phenolic part of this molecule, which was also critical for bioactivity ${ }^{[12,17,18]}$. In addition, the fluorobenzene part was located in the S2 subset, toward His475. Similar binding modes could also be found for other ligands.

Most of the selective agonists contained a hydrophobic group extended into the S2 subset, such as a fluorobenzene 

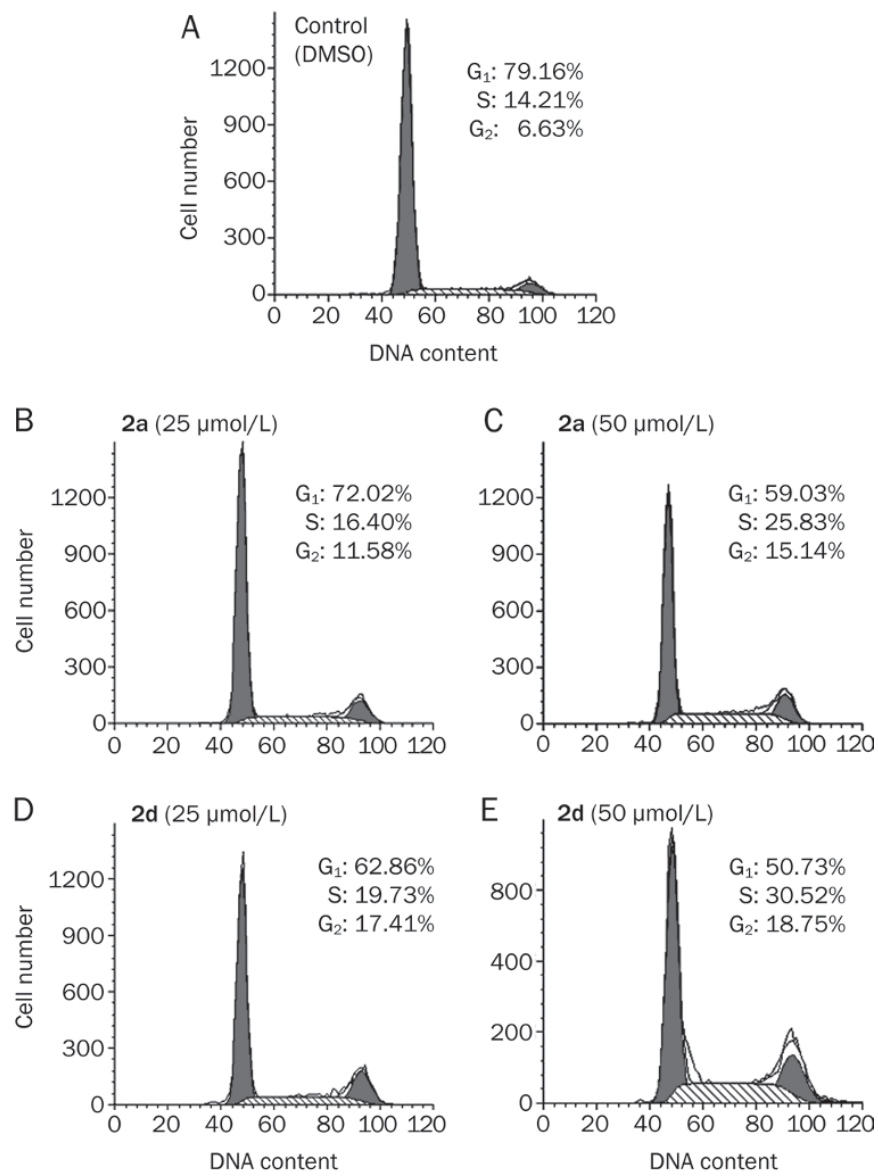

Figure 4. Effects of $\mathbf{2 a}$ and $\mathbf{2} \mathbf{d}$ on cell cycle distributions of MDA-MB-231 breast cancer cells. MDA-MB-231 cells were exposed to $25 \mu \mathrm{mol} / \mathrm{L}$ (B for compound $\mathbf{2 a}$, D for compound $\mathbf{2 d}$ ) and $50 \mu \mathrm{mol} / \mathrm{L}$ ( $\mathrm{C}$ for compound $\mathbf{2 a}$, E for compound 2d) compounds or the vehicle control (DMSO) (A) for $48 \mathrm{~h}$ before the cells were harvested, fixed, and stained with propidium iodide, and DNA content was evaluated by flow cytometry. Diagrams of cell cycle distribution $\left(G_{1}, S, G_{2}\right)$ were from one representative of three independent experiments with similar results.

or metoxybenzene. The S2 subset around the His 475 of ER $\beta$ seemed to accommodate a hydrophobic group. Comparison of $1 \mathrm{a}$ with $1 \mathrm{~d}$ revealed that the activity would increase when a chlorine atom was introduced into the phenol part. This result agreed with the conclusion that the introduction of polar groups on the phenol part could enhance the ER $\beta$ selectivity from our previous studies ${ }^{[19,20]}$. A similar phenomenon was also found in other $E R \beta$ selective ligands ${ }^{[21]}$.

Most of the antagonists had potent activity for both ER subtypes. A pharmacophore mapping of compound $\mathbf{2 a}$ showed that one hydrophobe feature was not matched, which might be the cause of reduced selectivity for ER $\beta$ (Figure 6D). Figure $6 \mathrm{~F}$ shows that $2 \mathbf{a}$ adopted a similar binding mode to $1 \mathbf{a}$. The phenolic part of $\mathbf{2} \mathbf{a}$ fitted well in the S1 subset and participated in the п-п interaction. A hydrogen bond network was formed with the phenolic hydroxyl group. Such interactions were also found in other antagonists. Moreover, two side chains of 2a occupied the S2 and S3 subsets. It is reported that the side
A

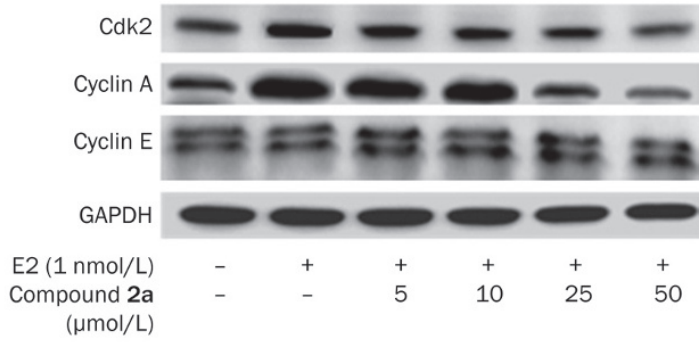

B

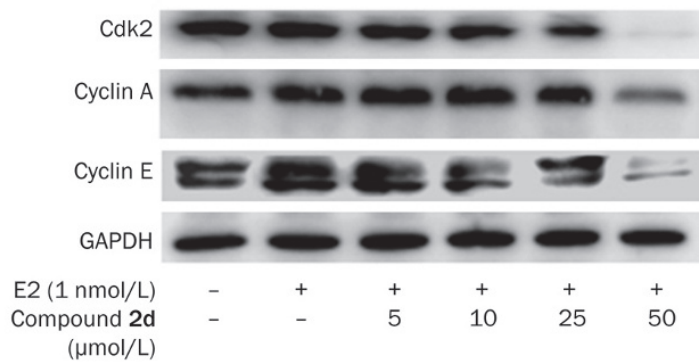

Figure 5. Immunoblot analysis for the expression levels of cell cycle regulatory proteins $2 \mathrm{a}(\mathrm{A})$ and $\mathbf{2 d}(\mathrm{B})$. MDA-MB-231 cells were treated with $\mathrm{E} 2$ or compounds at the indicated concentrations. Total cell lysates were prepared and equal amounts of protein $(40 \mu \mathrm{g})$ were subjected to SDS-PAGE followed by Western blot analysis. The indicated cell cycle regulatory proteins were recognized by antibodies against cyclin $A$, cyclin $E$, CDK2. GAPDH was used as an loading control. The Western blots shown here were representative of three independent experiments with similar results.

chain in the S3 subset could affect the conformation of Helix 12 and thus inhibit the function of the $\mathrm{ER}^{[22,23]}$. This indicated that the occupation of the S3 subset was important for ligand behavior and might explain the antagonism of $\mathbf{2 a}$.

In summary, with the combination of pharmacophore and docking-based virtual screening, 20 compounds were discovered as potent ligands of estrogen receptors. Through the $\mathrm{Y} 2 \mathrm{H}$ assay, 10 compounds were determined as agonists and 9 of them showed selective activity for ER $\beta$. A further similarity searching based on these highly selective agonists of ER $\beta$ is underway to identify compounds with stronger agonistic activity and higher ER $\beta$ selectivity. Moreover, we also found 8 antagonists among the 20 compounds. The ER antagonists exhibited better activity for ER $\beta$, which displayed higher antiproliferative potencies on ERa-negative MDA-MB-231 breast cancer cells than ERa-positive MCF-7 cells. We chose two antagonists, 2a and $\mathbf{2 d}$, which exhibited high antagonistic activity in the $\mathrm{Y} 2 \mathrm{H}$ assay and high antiproliferative activity, and these compounds were used to further explore the molecular mechanism underlying cell growth suppression. Flow cytometry and Western blot were used to analyze the cell cycle distribution and the expression levels of cell cycle regulatory proteins. Our results indicated that $2 \mathbf{a}$ and $\mathbf{2 d}$ could impair E2 induction, arrest MDA-MB-231 cells in the $S$ phase, and down-regulate the expression of cyclin A, CDK2, and cyclin $\mathrm{E}$, which are $\mathrm{S}$ phase-specific cell cycle regulatory proteins, which would subsequently repress cell proliferation. These 
A<smiles>CN(Cc1cccc(F)c1)C(=O)c1ccc(O)c(Cl)c1</smiles>

C

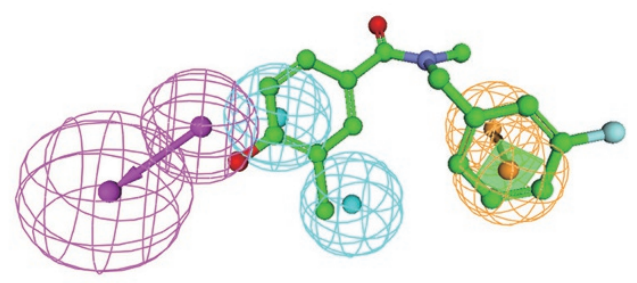

E

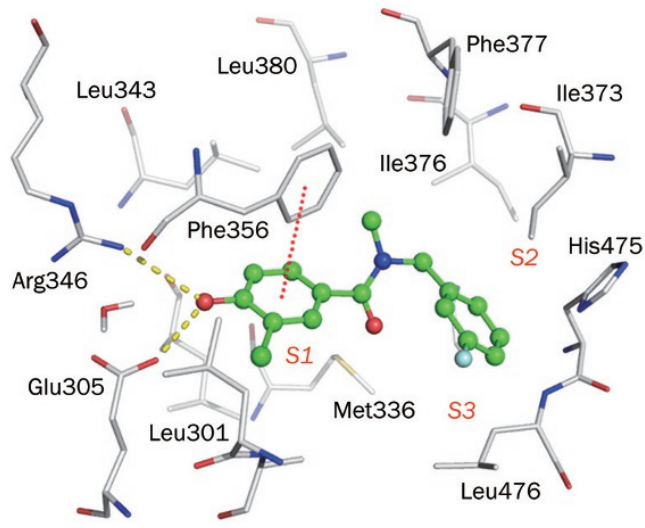

B<smiles>C/C(=N\N(c1ccccc1)c1ccccc1)c1ccc(O)cc1</smiles>

D

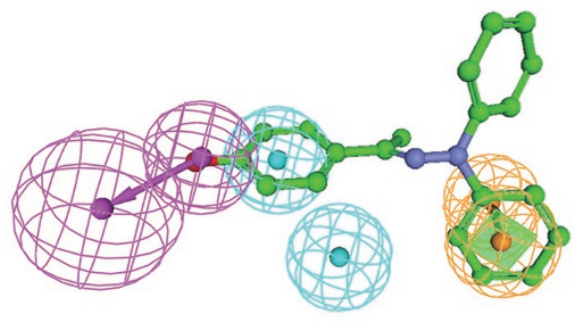

F

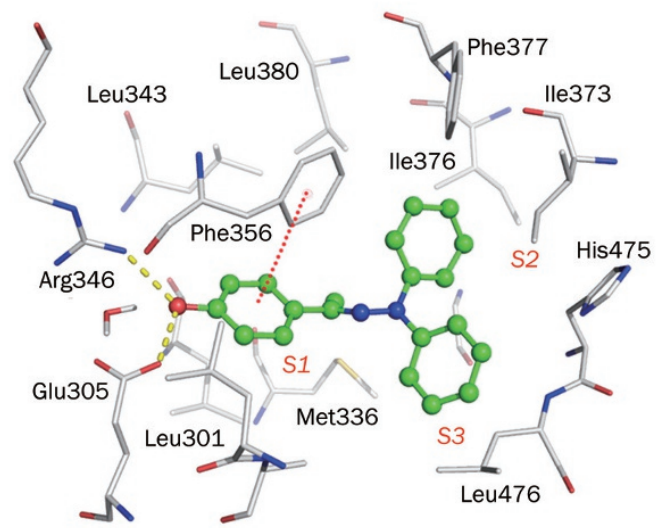

Figure 6. The 2D structures of agonist 1a (A) and antagonist 2a (B), 1a (C), and 2a (D) mapping onto ER 3 pharmacophore model, and the docking poses of $1 a(E)$ and $2 a(F)$ with the ligand binding domain (LBD) of ERß. The pharmacophore is represented in Catalyst form: hydrogen bond donor (HD, violet), hydrophobe (HY, blue), aromatic ring (RA, orange). The LBD consists of three hydrophobic subsets (S1, S2, and S3). Dash lines represent the non-covalent interaction between the ligand and receptor: yellow, hydrogen bonding; red, $\Pi-\Pi$ interaction. For clarity only the names of some critical residues are displayed.

active compounds reveal that the strategy combining pharmacophore and molecular docking was efficient in the discovery of selective leads, which could be used as potential molecular probes to explore the differences between the two subtypes of estrogen receptors.

\section{Acknowledgments}

This work was supported by the National Natural Science Foundation of China (№ 21072059, 81102420, and 81200415) and the Fundamental Research Funds for the Central Universities (No WY1113007).

\section{Author contribution}

Yun TANG, Shi-en ZOU, and Jin HUANG designed the research; Lei CHEN, Dang WU, Han-ping BIAN, Guang-lin KUANG, and Jing JIANG performed the research; Lei CHEN, Dang WU, Wei-hua LI, and Gui-xia LIU analyzed the data; Lei CHEN, Han-ping BIAN, Jin HUANG, and Yun TANG wrote the paper.

\section{Supplementary information}

Supplementary information is available at Acta Pharmacologica Sinica's website.

\section{References}

1 Kuiper GG, Carlsson B, Grandien K, Enmark E, Haggblad J, Nilsson $\mathrm{S}$, et al. Comparison of the ligand binding specificity and transcript tissue distribution of estrogen receptors alpha and beta. Endocrinology 1997; 138: 863-70.

2 Babiker FA, De Windt LJ, van Eickels M, Grohe C, Meyer R, Doevendans PA. Estrogenic hormone action in the heart: regulatory network and function. Cardiovasc Res 2002; 53: 709-19.

3 Korach KS, Emmen JM, Walker VR, Hewitt SC, Yates M, Hall JM, et al. Update on animal models developed for analyses of estrogen receptor biological activity. J Steroid Biochem Mol Biol 2003; 86: 387-91.

4 Hess RA. Estrogen in the adult male reproductive tract: a review. Reprod Biol Endocrinol 2003; 1: 52.

5 Weihua Z, Saji S, Makinen S, Cheng G, Jensen EV, Warner M, et al. Estrogen receptor (ER) beta, a modulator of ERalpha in the uterus. Proc Natl Acad Sci U S A 2000; 97: 5936-41.

6 Stettner M, Kaulfuss S, Burfeind P, Schweyer S, Strauss A, Ringert 
$\mathrm{RH}$, et al. The relevance of estrogen receptor-beta expression to the antiproliferative effects observed with histone deacetylase inhibitors and phytoestrogens in prostate cancer treatment. Mol Cancer Ther 2007; 6: 2626-33.

7 Barros RP, Machado UF, Gustafsson JA. Estrogen receptors: new players in diabetes mellitus. Trends Mol Med 2006; 12: 425-31.

8 Malamas MS, Manas ES, McDevitt RE, Gunawan I, Xu ZB, Collini MD, et al. Design and synthesis of aryl diphenolic azoles as potent and selective estrogen receptor-beta ligands. J Med Chem 2004; 47: 5021-40.

9 Harris HA. The unexpected science of estrogen receptor-beta selective agonists: a new class of anti-inflammatory agents? Nucl Recept Signal 2006; 4: e012.

10 Nilsson S, Koehler KF, Gustafsson JA. Development of subtypeselective oestrogen receptor-based therapeutics. Nat Rev Drug Discov 2011; 10: 778-92.

11 Meyers MJ, Sun J, Carlson KE, Marriner GA, Katzenellenbogen BS, Katzenellenbogen JA. Estrogen receptor-beta potency-selective ligands: structure-activity relationship studies of diarylpropionitriles and their acetylene and polar analogues. J Med Chem 2001; 44: 4230-51.

12 Li YQ, Xing XH, Wang H, Weng XL, Yu SB, Dong GY. Dose-dependent effects of genistein on bone homeostasis in rats' mandibular subchondral bone. Acta Pharmacol Sin 2012; 33: 66-74.

13 Yu SB, Xing XH, Dong GY, Weng XL, Wang MQ. Excess genistein suppresses the synthesis of extracellular matrix in female rat mandibular condylar cartilage. Acta Pharmacol Sin 2012; 33: 91823.

14 Shen J, Tan C, Zhang Y, Li X, Li W, Huang J, et al. Discovery of potent ligands for estrogen receptor beta by structure-based virtual screening. J Med Chem 2010; 53: 5361-5.

15 Fang J, Shen J, Cheng F, Xu Z, Liu G, Tang Y. Computational insights into ligand selectivity of estrogen receptors from pharmacophore modeling. Mol Inform 2011; 30: 539-49.

16 Discovery Studio, version 3.5. Accelrys, Inc; San Diego, CA, USA: 2012.

17 Schrödinger Suite; Schrödinger, LLC, New York, 2013.

18 Drwal MN, Griffith R. Combination of ligand- and structure-based methods in virtual screening. Drug Discov Today Technol 2013; 10: 395-401.

19 Shen J, Li W, Liu G, Tang Y, Jiang H. Computational insights into the mechanism of ligand unbinding and selectivity of estrogen receptors. J Phys Chem B 2009; 113: 10436-44.

20 Zeng J, Li W, Zhao Y, Liu G, Tang Y, Jiang H. Insights into ligand selectivity in estrogen receptor isoforms: molecular dynamics simulations and binding free energy calculations. J Phys Chem B 2008; 112: 2719-26.

21 Manas ES, Unwalla RJ, Xu ZB, Malamas MS, Miller CP, Harris HA, et al. Structure-based design of estrogen receptor-beta selective ligands. J Am Chem Soc 2004; 126: 15106-19.

22 Roelens F, Heldring N, Dhooge W, Bengtsson M, Comhaire F, Gustafsson JA, et al. Subtle side-chain modifications of the hop phytoestrogen 8-prenylnaringenin result in distinct agonist/antagonist activity profiles for estrogen receptors alpha and beta. J Med Chem 2006; 49: 7357-65.

23 Brzozowski AM, Pike AC, Dauter Z, Hubbard RE, Bonn T, Engstrom O, et al. Molecular basis of agonism and antagonism in the oestrogen receptor. Nature 1997; 389: 753-8.

This work is licensed under the Creative Commons Attribution-NonCommercial-No Derivative Works 3.0 Unported License. To view a copy of this license, visit http://creativecommons.org/licenses/ by-nc-nd/3.0/ 